\title{
REGIONAL GRAVITY SURVEY OF THE CALEDONIA HIGHLANDS AREA
} OF SOUTHERN NEN BRUNSWICK

KENNETH B.S. BURKE

Department of Geology, University of New Brunswick, Fredericton, New Brunswick

\section{INTRODUCTION}

This paper presents the results of a gravity survey over part of the Caldeonia Highlands, an uplifted area of basement rocks in southeastern New Brunswick (Fig. I). In 1970, the Caledonia Highlands was selected for an extensive geological mapping program by the New Brunswick Department of Natural Resources (DNR) and the Canadian Department of Regional Economic Expansion (DREE). This program was carried out during the years 1970 to 1972, with a multisensor geophysical (magnetic, VLF-EM and gamma ray spectrometer) survey being flown in 1971 to assist in the interpretation of the geological data (Ruitenberg et al 1973). The purpose of the gravity survey was to provide additional geological information, particularly on the deeper structure of the region.

Partial gravity coverage of the Caledonia Highlands already exists in the form of a 1:250,000 scale regional map of southeastern New Brunswick (Konecny 1966). Therefore the original intent of the gravity investigation was to complement this previous survey by filling blank areas and increasing the station density in other areas. However, as the study progressed, it was found that large elevation and tie-in errors were contained in the data of the previous survey. Therefore, most of the previously established gravity stations were re-measured. Because of the extra time and funds needed for this repetition, gravity coverage of the Caledonia Highlands was restricted to the western two-thirds of the region.

The survey area extends along the Bay of Fundy coast for approximately 100 kms, with a width varying between 15 and $30 \mathrm{kms}$ (Fig. 1). A total of 789 gravity stations was read along roads and trails. Measurements were taken with a Lacoste Romberg, Model G, Geodetic Gravity Metex (No 28), on loan from the Survey Engineering Department of the University of New Brunswick. Base stations of the Dominion Observatory network at St. John (Station 9846-62), Sussex (9209-68) and Alma (Station 9210-68) were used as control stations for the survey.

About $20 \%$ of the stations were read at New Brunswick Survey Control Stations, where elevation control was available to the nearest tenth of a foot $(.03 \mathrm{~m})$. For the remainder of the stations, elevations were determined by altimeter traverses between Survey Control Stations. Four altimeters ( 3 Paulin and $1 \mathrm{~K} . \mathrm{E}$. ) were used, and all stations were read at least twice ( 8 altimeter readings). If a significant discrepancy $(>3 \mathrm{~m})$ was noted in the two separate sets of readings, additional altimeter traverses were run until closer agreement was obtained. The maximum error in a station elevation will therefore be less than $3 \mathrm{~m}$, with most errors being considerably less. Station positions were plotted on 1:50,000 National Topographic Series maps, and latitude corrections were based on scaled estimates of latitudes from these maps.

Initially, Bouguer anomaly values were calculated using the International Gravity Formula of 1931 and values from the pre-June, 1974, gravity control station. These data were contoured and published in a series of gravity maps at a scale of $1: 50,000$ by the New Brunswick Department of Natural Resources, (Burke 1975). The Bouguer anomaly values plotted in Fig. 2 of the present paper have been recomputed to conform to the reference figure and network values now accepted for use in Canada, (McConnell, written comunication, 1974), by using the equation:

$(\Delta g)$ new $=(\Delta g)$ old $-0.95-13.6 \sin ^{2} \phi+0.05$ milligals where

$(\Delta g)$ new is the new Bouguer anomaly value

$(\Delta g)$ old is the Bouguer anomaly value based on IGF (1931) and pre June 1974 control values $\phi$ is the angle of latitude

Rock samples were collected from outcrops and their densities determined by hydrostatic weighing in the laboratory. Because of the paucity of outcrops it was not possible to collect truly representaiive samples for all of the different rock types. The density data have therefore been supplemented by using values obtained by other workers in the Atlantic Provinces and the state of Maine.

A geological map of the area of interest is shown in Figure 3. The rocks in this area have been described in detail by Hayes and Howell (1937), Alcock (1938), Kindle (1962), Van de Poll (1970) and Ruitenberg et al (1973a and b). Geological information, from $F$ igure 3 and the accounts of the above workers, pertinent to the interpretation of the gravity data, is sumarized in the following paragraphs.

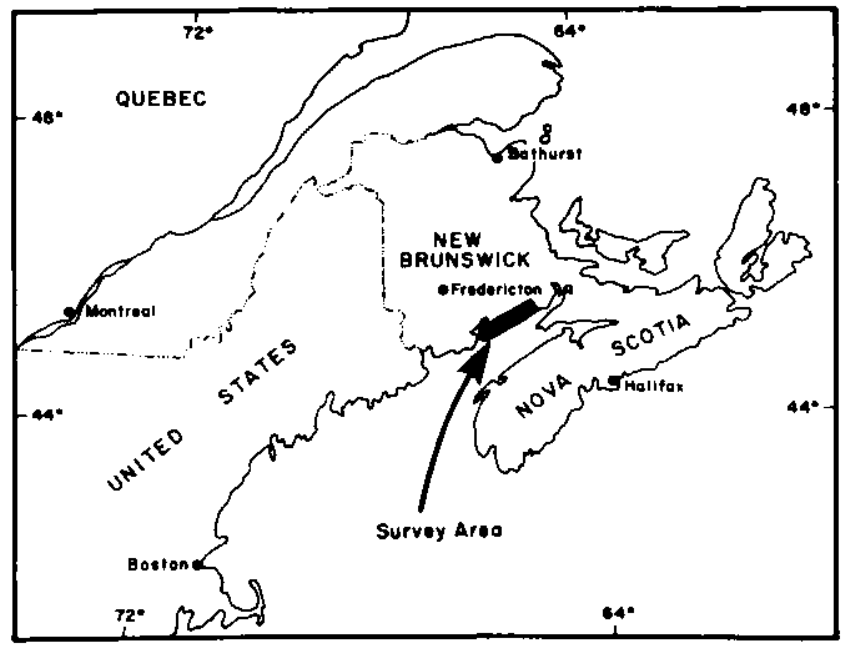

FIG. I Location map of survey area. 


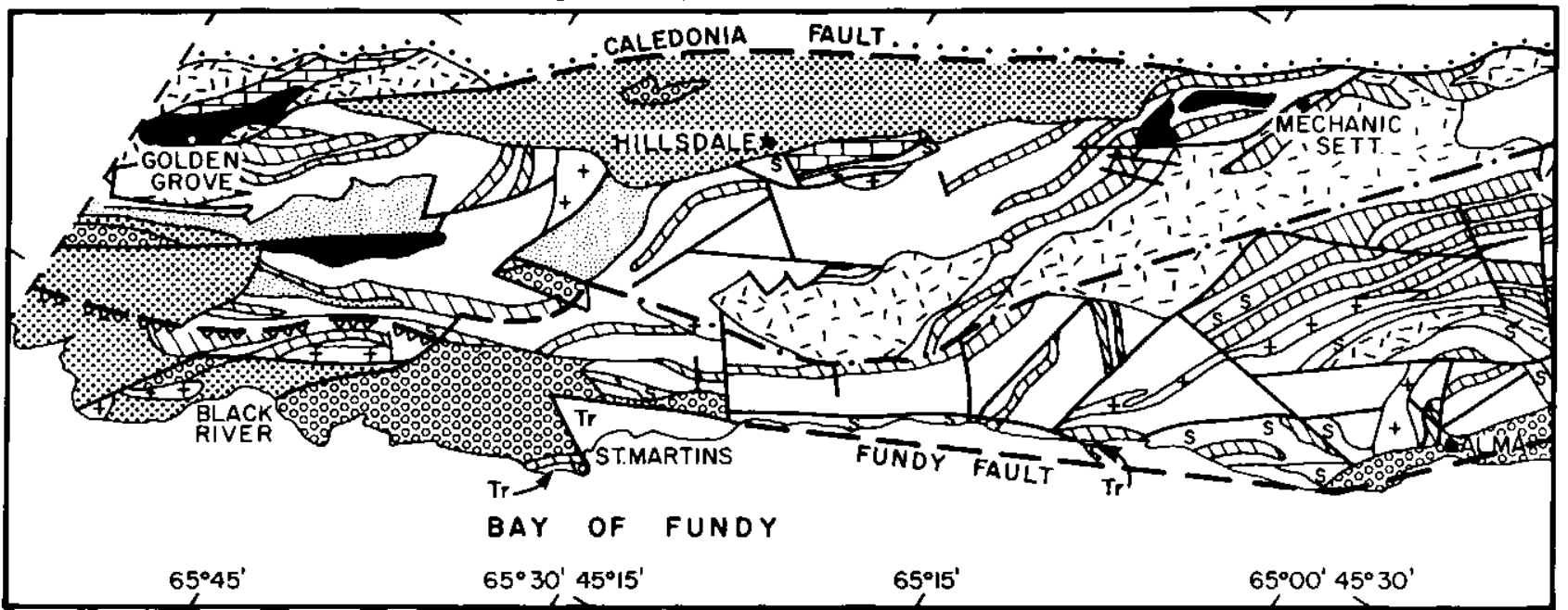

TRIASSIC

Tr Conglomerate, shole, sands tone LATE CARBONIFEROUS

\%용요 Sondstone, silts tone, conglomerate EARLY CARBONIFEROUS and/or LATE DEVONIAN

3. Cong., sandstone, siltstone, silicic 8 mafic flows and tutfs, minor intrusive rocks SILURIAN Or EARLIER

II II Argillaceous sedimentary rocks CAMBRIAN

Shale, sondstone, conglomerate, quartzite PRECAMBRIAN

$\square$ Moinly silicic flows and tuffs, minor mafics
Moinly mofic flows and tuffs, minor silicics
s Arkosic sondstone and conglomerote, quortzite
Simestohe, dolomite, gneisses and schists

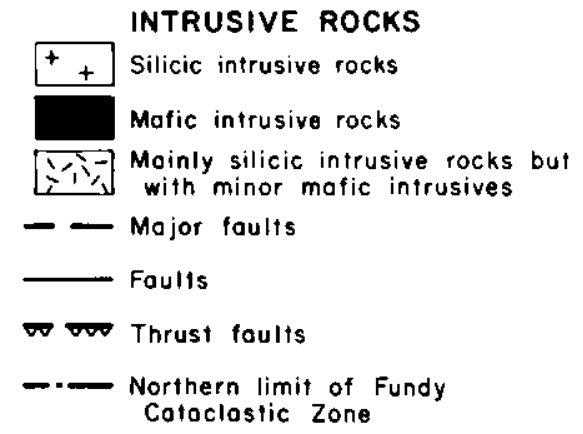

Map based moinly on Ruitenberg ef al (1973) with additions from Potter (1968) and Van de Poll (1971).

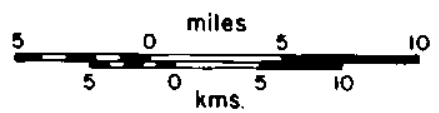

FIG. 2 Geological map of the Coledonia orea, southern New Brunswick.

\footnotetext{
Most of the area shown in Figure 3 is underlain by volcanic and sedimentary rocks of late Precambrian age, intruded by silicic and mafic rocks. Silicic rocks are exposed at the surface with mafic rocks being confined either to individual plutons, such as the one at Golden Grove in the northwest, or northeasterly trending bands of mafic volcanic flows, such as those northwest of Alma. Sedimentary rocks, predominantly of the coarse-grain, clastic type, and silicic volcanic rocks are interbedded with the mafic flows. A large plutonic body, consisting mostly of silicic intrusive rocks, is mapped as extending from northeast of Mechanic Settlement in a southwesterly direction towards st. Martins. Metamoxphosed calcareous sediments, gneisses and schists occur in two places: northeast of Golden Grove and southeast of Hillsdale. All of the above crystalline and well indurated rocks form the central core of the area and gravity anomalies here are likely to be related to changes in lithology or the presence of intrusions.
}

Southeast of Golden Grove, and also southwest of Hillsdale, blocks of Cambrian sedimentary rocks overlie, or are in faulted contact with Precambrian volcanic rocks. The southern boundary of the Hillsdale Cambrian sediments is marked by a fault contact with late Carboniferous sandstones, siltstones and conglomerates, the latter also lying on top of Precambrian volcanic rocks. Thus, there is good evidence that the central part of the area has been subjected to uplift in Paleozoic and possibly later times. Indeed, van de Poll (1970) has identified the Caldeonia Highlands as a major fault block, bounded in part by the Caledonia and Fundy Faults. The relatively low density of the sedimentary rocks should result in gravity lows being associated with the Cambrian and Carboniferous rocks.

Contact with Carboniferous rocks along the southern edge of the area is more complex. In the southwestern corner, the presence of a major thrust fault is needed to explain the overthrusting of 
TABLE 1

Densities of Rock Units

\begin{tabular}{|c|c|c|c|c|}
\hline Rock Unit & $\begin{array}{l}\text { Number of } \\
\text { Samples }\end{array}$ & $\begin{array}{l}\text { Range of } \\
\text { densitięs } \\
\left.\text { (gms/cm }{ }^{3}\right)\end{array}$ & $\begin{array}{l}\text { Mean } \\
\text { Density } \\
\left.\text { (gms/cm }{ }^{3}\right)\end{array}$ & $\begin{array}{l}\text { Standard } \\
\text { Deviatio̧n } \\
\text { (gms/cm })\end{array}$ \\
\hline \multicolumn{5}{|l|}{ Precambrian } \\
\hline Silicic flows & 40 & $2.61-2.76$ & 2.67 & \pm 0.05 \\
\hline Mafic flows & 57 & $2.70-2.92$ & 2.80 & \pm 0.07 \\
\hline Dolomite & 48 & $2.78-2.86$ & 2.83 & \pm 0.02 \\
\hline \multicolumn{5}{|l|}{ Cambrian } \\
\hline Sediments & 59 & $2.54-2.70$ & 2.61 & \pm 0.04 \\
\hline \multicolumn{5}{|c|}{ Early Carboniferous/Late Devonian } \\
\hline Sediments & 91 & $2.59-2.80$ & 2.70 & \pm 0.04 \\
\hline \multicolumn{5}{|l|}{ Late Carboniferous } \\
\hline Sediments & 40 & $2.53-2.67$ & 2.64 & \pm 0.03 \\
\hline \multicolumn{5}{|l|}{ Triassic } \\
\hline Sandstone & 18 & $2.42-2.58$ & 2.49 & \pm 0.04 \\
\hline \multicolumn{5}{|c|}{ Silicic Intrusive Rocks } \\
\hline Granite & 39 & $2.59-2.77$ & 2.64 & \pm 0.04 \\
\hline Granodiorite & 15 & $2.70-2.79$ & 2.77 & \pm 0.02 \\
\hline \multicolumn{5}{|l|}{ Mafic Intrusive Rocks } \\
\hline Gabbro & 19 & $2.83-3.02$ & 2.94 & \pm 0.05 \\
\hline
\end{tabular}

Carboniferous and older rocks onto the central block. The Late Devonian and Early Carboniferous sedimentary rocks are also accompanied by volcanic and intrusive rocks. To the east, the above rocks are separated from sandstones, siltstones and conglomerates of Late Carboniferous age, by a northeasterly trending fault, the latter extending along the coastline between Black River and St. Martins.

At St. Martins, faulted blocks of Triassic sandstones conglomerates and shale are exposed, together with a thin slice of volcanic rocks of probable Precambrian age. A fault block of Triassic rocks also occurs about $30 \mathrm{kms}$ to the east along the Fundy Fault (Fig. 3), and similar rocks and structures are known to underlie the Bay of Fundy. At Alma, sandstones, siltstones and conglomerates of Late Carboniferous age are exposed. The contrast between the lower density of the Carboniferous and Triassic sediments and the higher density of the crystalline rocks of the uplift should cause changes in gradients of the gravity contours.

To the north of the uplifted block lies the Moncton asin, containing mainly sandstone, siltstones and conglomerates of Carboniferous age. The contact of the Carboniferous rocks with the Precambrian rocks appears to be that of normal, or high-angle reverse, faulting. At a few locations, masses of low density evaporites have accumulated and given rise to distinct gravity lows (Burke 1971).

\section{DENSITY VALUES}

Densities of a variety of rock types, collected in the survey area, were determined from the results of weighing samples in air and water. Samples of Triassic sandstone, Carboniferous sediments and Cambrian sediments were covered with water in a flask connected to a vacuum pump, for one week before measurements were made. In this way, saturated densities of these rocks were determined. Because the rest of the samples were from wellindurated rocks of low porosity, they were not subjected to the same saturation process. A sumary of the density values obtained is contained in Table I, where values have been grouped to conform to the units identified on the accompanying geological map in Figure 3.

The mean density of mafic intrusive rocks is higher than the densities of all other units and therefore mafic intrusions can be expected to be associated with the larger gravity highs. Similarly, the Triassic sandstone has a mean density less than the other rock units and therefore is expected to be associated with low Bouguer anomaly values. The granodiorite, mafic flow and dolomite samples all have similar densities and can only be expected to produce significant Bouguer anomalies where they are in contact with other rock types. In the same way, the remaining sedimentary rocks, silicic flows and granites are in the same density range and must be in contact with the other rock types in order to give identifiable Bouguer anomalies. 


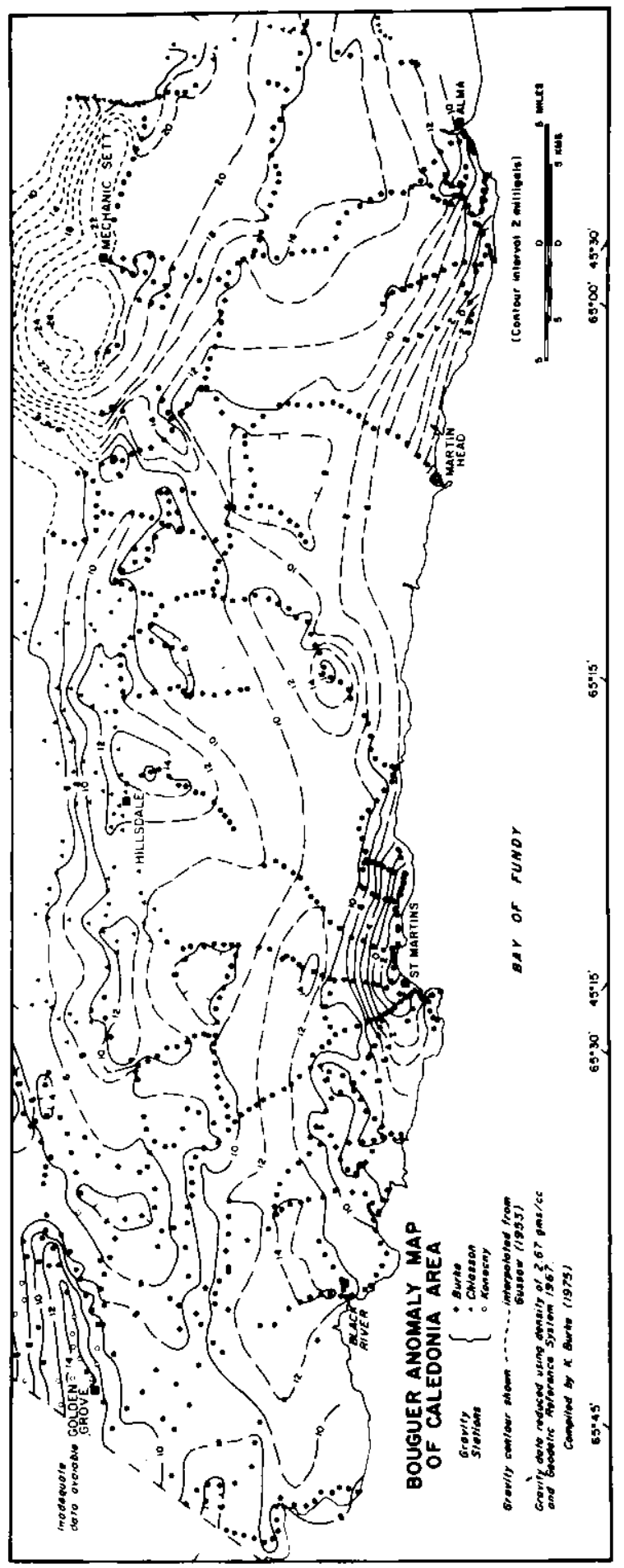

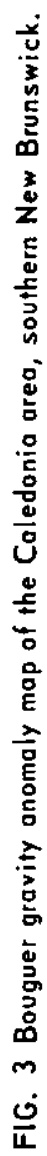


A more detailed discussion of the densities of rocks collected from this area is contained in Gupta and Burke (1977).

\section{CORREIATION OF BOUGUER ANOMALY VALUES AND MAPPED GEOLOGY}

Bouguer anomaly values range between $-10 \mathrm{milli}-$ gals and +26 milligals in the survey area. From a comparison of the Bouguer anomaly map (Fig. 2) with the geological map (Fig. 3), it is seen that the higher values (>10 milligals) are generally associated with the uplifted basement rocks of Precambrian to Lower Paleozoic age, whereas the lower values ( $<10$ milligals) are mainly associated with the surrounding Carboniferous and Triassic sediments.

Along the Fundy Bay coast, near St. Martins and Martin Head, there is a considerable steepening in the gradient of the gravity contours. These steep gradients coincide with the faulted contact between the Triassic rocks and the older sediments and uplifted basement rocks. A minimum thickness of $1.6 \mathrm{~km}$ of low density Triassic sandstone is needed to account for the onshore part of the gravity low outlined in the st. Martins area. Where volcanic rocks outcrop to the southwest of St. Martins, this gravity low is modified by the development of a ridge of higher gravity values. The development of this ridge suggests that a relatively thick (1-2 $\mathrm{km}$ ) block of older (Coldbrook?) volcanic rocks is present at this location. A detailed local gravity survey is required to investigate the dimensions of this block quantitatively.

More gradual gravity gradients are associated with the contact between Carboniferous rocks and uplifted basement rocks in the southwest and southeast of the survey area. Smaller density contrasts and shallower attitudes of fault contacts are probable explanations for these decreases in gradients. In the northern part of the area, the gravity gradients steepen again, suggesting that high-angle faults form the major boundary between the older and younger rocks. Evaporite deposits to the north of Hillsdale also contribute to the rapid decrease in Bouguer anomaly values in a northerly direction.

Over the Caldeonia Highlands uplift, the highest Bouguer anomaly values occur in association with two mafic intrusions; one at Mcchanic settlement and one at Golden Grove. The northern portion of the anomaly at Mechanic settlement was mapped in a gravity survey included in a paper by Gussow (1953). The lack of mapped exposures of mafic intrusive rocks at the surface suggests that a more extensive development of high density (mafic) rocks must occur at depth in order to explain the areal extent of the gravity high. Thus this intrusion may be a major volcanic centre for the region.

The Golden Grove intrusion is marked by a distinct closed high of 6 milligals, with the anomaly again extending beyond the mapped northern boundary of the intrusion. However, there is a block of dolomitic limestone present with a density that is only $0.1 \mathrm{gms} / \mathrm{cm}^{3}$ less than the gabbro forming the Golven Grove intrusion. Therefore, the gravity high is probably associated with both rock types.

The mapped mafic intrusive rocks, $9 \mathrm{kms}$ southeast of Golden Grove, are reflected only by a small nosing of the gravity contours. This suggests that the mafic rocks present are relatively limited in extent. The exposure probably represents part of a thin slice of mafic rocks caught up along the northeast trending fault.

Rocks that are mapped as distinctly silicic intrusives have none or only one or two gravity stations within their exposed boundaries. It is therefore difficult to assess the effect of these low density rocks on the Bouguer anomaly contours. There is some minor nosing of contours associated with the silicic intrusive rocks, $2 \mathrm{kms}$ west of Alma, but the minor nature of the change in the contour pattern suggests only a small pluton. All other units mapped as distinctly silicic intrusive rocks show no direct influence on the Bouguer anomaly contours.

A zone of mainly silicic intrusive rocks is mapped that extends from about $11 \mathrm{kms}$ east of Mechanic Settlement to $13 \mathrm{kms}$ northeast of St. Martins. Low values would be expected to dominate the gravity field over these rocks, particularly if they represent a pluton with a significant depth extent. However, it is only over the central one third of the zone that a gravity low is developed and the small magnitude and gradient of this anomaly suggests a maximum depth extent of only 2 kms. In the northeastern part of this zone, the influence of the Mechanic Settlement mafic intrusion may be masking the contribution of the lighter silicic rocks to the gravity field.

Most of the areas of Precambrian silicic flows are not represented by the development of really distinctive lows in the Bouguer anomaly contour map. This suggests that the flows are generally thin. In the area to the east of Hillsdale, three minor gravity lows may be associated with the development of greater thicknesses of silicic flows. In other areas, the silicic flows do not have a marked influence on the Bouguer anomaly contours.

In contrast, areas of mafic flows have a significant influence on the Bouguer anomaly contour map. An elongated gravity high is associated with a zone of predominantly mafic flows, extending from north of St. Martins to Black River. The mafic flows, north of Alma, are marked by a region of relatively high Bouguer anomaly values. The mafic flows, southwest of Mechanic settlement, are associated with a ridge of gravity highs that extend to the St. Martins area. Other mafic flows are either too close to major anomalies (e.g. Golden Grove), or not adequately enough covered by gravity stations for their influence on the Bouguer anomaly values to be assessed.

As already mentioned, the density of the Precambrian dolomitic limestone, exposed to the north of Golden Grove, is almost as high as the gabbroic rocks in this area and both rock types contribute to the gravity high. The limestone mapped to the 
east of Hillsdale is also associated with a gravity high.

The Precambrian arkosic sandstones, conglomerates and quartzite do not appear to influence the Bouguer anomaly contours. However, exposures of Cambrian rocks to the east of Golden Grove, and to the southwest of Hillsdale, are associated with closed gravity lows. A reliable estinate of the thickness of the Cambrian rocks is not possible because of the presence of silicic flows and Carboniferous rocks with similar densities to the Cambrian sediments.

\section{GRAVITY ANOMALIES UNREIATED} TO SURFACE GEOLOGY

Most of the gravity anomalies are associated with lithological changes mapped in the surface gcology. However, in some parts of the area, there appears to be no relationship between the gravity anomalies and the rock types exposed at the surface. An explanation for these anomalies must therefore be sought in the development of density contrasts at greater depths.

The clearest example is the gravity high to the southeast of Hillsdale, which occurs in a place where mostly silicic flows have been mapped. Higher density, probably more mafic flows may underlie these silicic flows. Another possibility is the extension at depth of the Greenhead limestone that outcrops to the east of the anomaly. Whatever the source of the anomaly, if we assume a sheet-like mass, the maximum depth to its upper surface is only $0.75 \mathrm{kms}$.

About $10 \mathrm{kms}$ northeast of Golden Grove, an extensive gravity low is developed. The centre of the anomaly lies in an area where mainly mafic flows and tuffs are exposed at the surface, although the flanks of the anomaly are underlain by Cambrian sediments. It is proposed that the source of this anomaly is a buried pluton of lighter, probably more silicic, rocks.

The other example is related to the extension of gravity anomalies beyond the boundaries of the causative rock units mapped at the surface. For instance, the relatively high Bouguer anomaly values, and large areal extent, of the Mechanic gettlement anomaly suggest that the high density mafic rocks have a more extensive development at depth than is revealed by the surface geology map. The generally high Bouguer anomaly values over the whole eastern portion of the survey area suggest that the upper crust in this portion must contain a higher proportion of high density rocks than the western portion. On the basis of trend analysis of aeromagnetic maps, Tferian (1974) has proposed a mafor crustal break along a line between St. Martins and Mechanic Settlement. The gravity evidence thus suggests that there may be a difference in the nature of the two crustal blocks on each side of this line.

\section{CONCLUSIONS}

The pattern of positive Bouguer anomalies over most of the Caldeonia Highlands uplift indicates the predominance of high density, probably mafic, rocks in the upper part of the crust in this area. Silicic rocks of lower density are confined to relatively thin sheets with a limited depth extent, there being no evidence in the gravity data of large batholiths of granitic rocks. A major crustal discontinuity appears to divide the uplifted block into two segments along a line between St. Martins and Mechanic Settlement. The level of gravity anomaly values is similax on both sides of the mapped northern boundary of the 'Fundy Calaclastic zone' (Figs. 2 and 3 ). There is therefore no support in the gravity anomalies for the 'Fundy Calaclastic Zone' of Ruitenberg et al (1973b) being associated with a major change in the structure of the crust.

The boundaries of many of the mapped rock units are associated with changes in the Bouguer gravity values. For example, the high density, mafic, intrusive rocks are indicated by closed highs or nosing of contours. However, in all cases, a more detailed coverage with gravity stations is desirable before reliable estimates can be made of the shape and depth extent of individual rock units. In some cases, the determination of contact relationships will be difficult to achieve on the basis of the gravity information alone. For instance, contacts between the Golden Grove mafic intrusion and the Green Head limestone do not yield a distinct gravity anomaly change because of the small density contrast between the two rock types. A combination of magnetic and gravity investigations might help in this case.

The steep gravity gradients over most of the boundary faults suggest that high-angle blockfaulting has played a major role in the uplift of the Caledonia Highlands. In the southwest, however, more gradual gravity gradients associated with the faults between the Carboniferous and older rocks are consistent with the presence of relatively low-angle thrust-faulting. Similar thrust faults have been described in the area southwest of St. John by Rast and Grant (1973). Other evidence of possible thrusting in this area is provided by the relatively small gravity anomaly associated with a block of mafic intrusive rocks, mapped $9 \mathrm{kms}$ southeast of Golden Grove (compare the magnitude of this anomaly with that of the Golden Grove anomaly over a similar area of mafic rocks). This block of mafic rock may therefore represent a thin slice transported over the underlying older rocks, by means of thrust-faulting.

\section{ACKNOWLEDGEMENTS}

The author gratefully acknowledges a Geological Survey of Canada and National Research Council of Canada grant that covered the expenses of the field work. He also thanks J.B. Ross and R. McCulloch who prepared the figures, C. Brien and $S$. Townsend who typed the manuscript and $D$. Noble who assisted with the density measurements.

\section{REFERENCES}

ALCOCK, F.J., 1938, Geology of Saint John region. Geol. Survey Can. Mem. 216, 65 pP.

BURKE, K.B.S., 1971, Gravity survey over possible 
BURKE, K.B.S. (cont.)

salt structures in the Plumweseep-Penobsquis area of New Brunswick, 1lp. in Exploration of a salt potash prospect., New Brunswick Mineral Resource Branch Special Report, August 1971.

1975, Bouguer Anomaly Maps 75-1, $75-2,75-3,75-4,75-6,75-7,75-8$, New Brunswick Department of Natural Resources Map Series.

GUPTA, V.K. and BURKE, K.B., 1977, Density and magnetic susceptibility measurements in southeastern New Brunswick., Can. Jour. Earth Sci. vol. 14, pp. 128-132.

Gussow, w.C., 1953, Carboniferous stratigraphy and structural geology of New Brunswick, Canada., Bull. Am. Assoc. Pet. Geol. Vol. 37, pp. 1713-1816.

HAYES, A.O. and HOWELL, B.G., 1937, Geology of Saint John, New Brunswick, Geol. Soc. Am. Spec. Paper 5, $146 \mathrm{pp}$.

KINDLE, E.D., 1961, Geology Point Wolfe, Map 1109A, Geol. Sur, of Canada.

KONECNY, G., 1966, Amherst Sheet. 21H, 1:250,000,
New Brunswick Gravity Survey, Department of Mines and Technical Services.

RAST, N. and GRANT, R., 1973, Transatlantic correlation of the Variscan-Appalachian orogeny. Am. Jour. Sci., 373, pp. 572-579.

RUITENBERG, A.A., VENUGOPAL, D.V. and GILES, P.S., 1973a, Fundy Cataclastic Zone, New Brunswick: Evidence for post Acadian penetrative deformation., Geol. Soc. Am. Bull, 84, pp. 30293044 .

GILES, P.J., VENUGOPAL, D.V. and MCCUTCHEON, S.R., 1973b, A brief summary of the late Precambrian rocks in the Caledonia Highlands of southeastern New Brunswick, Maritime Sediments, Vol. 9, pp. 83-87.

TEJERIAN, H.G., 1974, Trend analysis of aeromagnetic data in the Calecionia area of New Brunswick, M.Sc. thesis, Univ. of New Brunswick, 249 pp.

VAN DE POLL, H.W., 1970, Stratigraphical and sedimentological aspects of Pennsylvanian strata in southern New Brunswick, Ph. D. thesis, Univ. of wales, $123 \mathrm{pp}$. 